\title{
STRATEGIC MANAGEMENT IN STRENGTHENING MADRASAH ORGANIZATIONAL CULTURE
}

\author{
(Multisite Study at MTsN 16 Jombang and MTsN 1 Ponorogo, Indonesia) \\ Bambang Wiyono ${ }^{1}$, Imam Fuadi ${ }^{2}$, Nur Efendi ${ }^{3}$ \\ 1, Doctoral Program of UIN Sayyid Ali Rahmatullah Tulungagung, \\ ${ }^{2,3}$ UIN Sayyid Ali Rahmatullah Tulungagung
}

\begin{abstract}
This research is motivated by the reality that strategic management has enormous benefits for an organization to increase the effectiveness and efficiency of programs to achieve the goals that have been set. The benefits of strategic management include being able to identify possible threats from the environment so that they can be avoided as early as possible, being able to create synergy and organizational spirit to increase productivity, and being able to adjust the direction of the organization's journey with the mission and goals to be achieved. Strategic management is an effective alternative to strengthen the organizational culture of an educational institution, including madrasa institutions. The approach in this study uses a qualitative approach with the type of research being a multi-site study. Data collection techniques using in-depth interviews, participant observation, and documentation. data is analyzed repeatedly through single data analysis and cross-site analysis. The findings of this study are 1) Formulation of strategies for strengthening madrasah organizational culture is based on internal analysis through Madrasah Self-Evaluation (EDM) and also SWOT analysis. 2) Implementation of strategies for strengthening madrasah organizational culture is carried out through program formulation activities as a derivative or elaboration of the strategic program formulations determined in the planning, organizational structure, and HR placement stages by their competencies 3) Evaluation of strategies for strengthening madrasa organizational culture is carried out by comparing performance achievements with indicators of program success that have been set at the beginning. Evaluation activities are carried out by involving all components of the madrasa and external parties by prioritizing the principles of togetherness, kinship, and openness as well as religious values to obtain objective evaluation results.
\end{abstract}

Keywords: Strategic Management, Cultural Strengthening, Madrasah Organization

\section{RESEARCH CONTEXT}

Strategic management has enormous uses or benefits for an organization including the organization of educational institutions to increase the effectiveness and efficiency of programs to achieve predetermined goals. The benefits of strategic management include being able to identify possible threats or disturbances from the environment, both internal and 
external so that they can be avoided or minimized as early as possible. In addition, strategic management can create synergistic cooperation and organizational spirit to increase productivity and be able to adjust the direction of the organization's journey with the mission and goals to be achieved. ${ }^{1}$

In research conducted by Gunawan, it is stated that strategic management has a high level of effectiveness in realizing the independence of Islamic boarding schools ${ }^{2}$. Research conducted by S. Ali Jadid Al Idrus also found the effectiveness of strategic management in developing higher education in Islamic boarding schools. ${ }^{3}$ In addition, the findings of research conducted by Aries Musnandar stated that the implementation of strategic management was able to develop the organizational culture of Islamic universities. ${ }^{4}$

On the other hand, the organization has positive values that make them superior compared to its competitors. ${ }^{5}$ Sadri and Lees state that competitive advantage can be created with a good organizational culture. This means that organizational culture will affect competitive advantage. ${ }^{6}$ Flatt and Kowalczyk argue that organizational culture is an intangible asset that is used to create competitive advantage, namely as a differentiator with other organizations and is used to improve organizational performance. ${ }^{7}$

${ }^{1}$ J. Salusu, Pengambilan Keputusan Strategi untuk Organisasi Publik dan Organisasi Nonp rofit (Jakarta: Grasindo, 2008), 495.

${ }^{2}$ Gunawan, Manajemen Strategik dalam Mewujudkan Kemandirian Pondok Pesantren (Studi Multisitus di Pondok Pesantren Sidogiri Pasuruan dan Pondok Pesantren Al-Islah Bondowoso), Disertasi (Malang: Pascasarjana UIN Malang, 2014).

${ }^{3}$ S. Ali Jadid Al Idrus, Manajemen Strategik Pengembangan Pendidikan Tinggi di Pondok Pesantren (Studi Multisitus di Pondok Pesantren Salafiyah Syafi'ah Sukorejo Situbondo, Pondok Pesantren Qomarul Huda Bagu Lombok Tengah, dan Pondok Pesantren Darunnahdlatain Nahdlatun Wathan Pancor Lombok Timur), Disertasi (Malang: Pascasarjana UIN Malang, 2014).

${ }^{4}$ Aries Musnandar, Implementasi Manajemen strategikk dalam Pengembangan Budaya Organisasi pada Perguruan Tinggi Islam: Studi Kasus di UIN Maliki Malang” ( Jurnal Ulul Albab Volume 14, no.1 Tahun 2013 )

${ }^{5}$ Angel Caroline Lukito, Devine, Pengaruh Budaya Perusahaan terhadap Keunggulan Bersaing Melalui Kepuasan Karyawan pada Perusahaan Kafe Restauran di Surabaya (Surabaya: Jurnal Business Accounting Rewiew, Vol. 3, No. 1, Januari 2015), 280-291.

${ }^{6}$ Golnaz Sadri dan Brian Lees, Developing Corporate Culture As a Competitive Advantage(The Journal Of Management Development, Vol. 20, No. 10, 2001), pp. 853-859.

${ }^{7}$ Sylvia J. Flatt, Stanley J. Kowalczyk, Creating Competitive Advantage Through Intagible Asset: The Direct and Indirect Effects of Corporate Culture and Reputations (Advances in Competitiveness Research, Vol. 16, 1\&2, 2008), pg.13. 
Furthermore, Nayak and Barik added that organizational culture makes a significant contribution to influencing thoughts, feelings, relationships, and organizational performance ${ }^{8}$ Thus, it can be concluded that educational institutions. will be able to achieve a competitive advantage if it has a good organizational culture. Educational institutions must be able to create a positive organizational culture that can influence the implementation of quality education and the formation of positive attitudes and morals for all human resources in educational institutions.

Organizational culture plays an important role in improving the performance of human resources in an organization. Organizational culture serves as a binder for all components of the organization, determines identity, injection of energy, motivator, and can be used as a guide for members of the organization. An organizational culture is an adhesive tool that can make organizational groups closer and can be a positive energy that can bring the organization in a better direction. A strong organizational culture will of course be able to increase the effectiveness of the organization in achieving its goals. And vice versa, a weak organizational culture will make it difficult to realize the goals that have been set. ${ }^{9}$

Organizational culture has a function as a meaning-making and control mechanism that directs and shapes the attitudes and behavior of employees or leaders in the organization. This will also indirectly create a mechanism that streamlines the work of the organization concerned. ${ }^{10}$ Furthermore, the results of research conducted by Nayak and Barik, stated that it would lead to a positive relationship between organizational culture and employee job satisfaction. ${ }^{11}$

Responding to these problems, the development of a good organizational culture needs to be considered and carried out in achieving the success of educational institutions. This success, namely succeeding in becoming an educational institution that is competitive and able to meet the needs of the community. Organizational culture is also needed to respond to

\footnotetext{
${ }^{8}$ Bandana Nayak, Anil Barik, Assessment Of The Link Between Organizational Culture and Job Satisfaction (Study of An Indian Public Sector) (International Journal Of Informations Business and Management, 2013, Vol. 5, No. 4).

${ }^{9}$ Aries Musnandar, Implementasi Manajemen Strategikk dalam Pengembangan Budaya Organisasi pada Perguruan Tinggi Islam: Studi Kasus di UIN Maliki Malang (Jurnal Ulul Albab Volume 14, No.1 Tahun 2013), 72.

${ }^{10}$ Eny Wahyu Suryanti, Pengembangan Budaya Organisasi di Sekolah (Jurnal Likhitaprajna Volume 19, Nomor 1), $1-12$.

${ }^{11}$ Bandana Nayak, Anil Barik, Assessment Of The Link Between...,Vol.5, No. 4.
} 
rapidly changing external conditions which are a challenge to the existence of educational institutions. One of the concepts that can be offered in building a good organizational culture in educational institutions is strategic management.

\section{THEORETICAL REVIEW}

\subsection{Strategic management}

Strategic management is a combination of two words, namely management and strategy, each of which has its meaning. Furthermore, when assembled into one combined phrase it will have a new meaning. Before explaining the meaning or meaning of strategic management as a whole, we will explain the meaning of the words management and strategy. According to J. Echols, the word management comes from the word manage which means to manage, organize, implement and manage. ${ }^{12}$ In the Popular Scientific Dictionary, the word management is defined as business processing, management, management of resources effectively to achieve the desired goals. ${ }^{13}$ Terry said management is the achievement of predetermined organizational goals with the help of others. ${ }^{14}$ Hadari Nawawi defines management as the ability of managers to utilize other people through activities and develop cooperation in achieving organizational goals effectively and efficiently. ${ }^{15}$ From some of the meanings and understandings of the word strategy above, it can be concluded that management is the ability of leaders to process existing resources and to influence and move their subordinates optimally to work together to achieve organizational goals.

The word strategy is defined as the science of war tactics to achieve something. ${ }^{16}$ From this understanding, the term strategy is often used in military circles which means a path or science to win a war. However, with the development of the times to date, strategies can be used in various organizations to achieve a goal and are used as a way to win the competition or competitiveness. Strategy is also defined as the main tips, methods, and tactics designed

\footnotetext{
${ }^{12}$ John Echols dan Hasan Syadily, Kamus Inggris Indonesia (Jakarta: Gramedia, 1996), 372.

${ }^{13}$ Pius A. Partanto \& M. Dahlan Al Barry, Kamus Ilmiah Populer (Surabaya : Arkola, 2001), 440.

${ }^{14}$ George R. Terry, Prinsip-Prinsip Manajemen, terj. J. Smith D.F.M (cet. 10, Jakarta : PT Bumi Aksara), 9.

${ }^{15}$ Hadari Nawawi, Manajemen Strategik Organisasi Nonprofit Bidang Pemerintahan dengan Ilustrasi di Bidang Pendidikan (Cet. III, Yogyakarta: Gadjah Mada University, 2005), 38.

${ }^{16}$ Pius A. Partanto \& M. Dahlan Al Barry, Kamus Ilmiah..., 732.
} 
systematically in carrying out management functions that lead to the strategic objectives of the organization. ${ }^{17}$

Wheelen and Hunger argue that organizational strategy is a comprehensive planning formulation about how an organization will achieve its vision, mission, and goals. The strategy will maximize competitive advantage and minimize competitive limitations. ${ }^{18}$ From the several definitions of strategy above, it can be explained that strategy is a careful way or plan to achieve certain goals or objectives. Strategy is very important in doing everything to achieve a goal. By using a strategy in doing everything it will make activities more efficient and goals will be easily achieved.

Then when the words management and strategy are combined into one, the combination will have a new meaning. David defines strategic management as "Strategic management can be defined as the art and science of formulating, implementing, and evaluating cross-functional decisions that enable an organization to achieve its objectives. "19 David also explained that strategic management is the science of formulating, implementing, and evaluating cross-functional decisions that enable an organization to achieve its goals. ${ }^{20}$ Akdon defines strategic management as the art, technique, and science of formulating, implementing, evaluating, and supervising various organizational functional decisions that are always influenced by the constantly changing internal and external environment to provide the organization with the ability to achieve goals as expected. ${ }^{21}$

Jauch and Glueck also define strategic management as some decisions and actions that lead to the preparation of a strategy or some effective strategies to help achieve company goals. $^{22}$ Prof. Dr. Sondang P. Siagian defines strategic management as a series of fundamental decisions and actions made by top management and implemented by all levels of an organization to achieve the goals of the organization. ${ }^{23}$

\footnotetext{
${ }^{17}$ Hadari Nawawi, Manajemen strategik...,147-148.

${ }^{18}$ David J. Hunger dan Thomas L. Wheelen, Manajemen strategiks, terj. Julianto Agung S (Cet. 16, Yogyakarta: Andi, 2003), 16.

${ }^{19}$ Fred R David, Strategic Management: Concepts, Upper Saddle River, N.J. : Prentice Hall, @2011.

${ }^{20}$ Fred R. David, Manajemen Strategiks (Jakarta: PT. Indeks Kelompok Gramedia, 2014), 5.

${ }^{21}$ Akdon, Strategic Management for Educational Management, (Bandung : Alfabeta, 2006), 5.

${ }^{22}$ Lawrence R. Jauch dan Wiliam F. Gluech, Manajemen strategiks dan Kebijakan Perusahaan (Jakarta : Erlangga, 1998), 52

${ }^{23}$ Sondang P. Siagian, Manajemen Stratejik (Jakarta : Bumi Aksara, 2005), 15.
} 
From the several notions of strategic management above, it can be described that strategic management is the science of formulating a strategic plan, implementing or implementing, and evaluating a decision or policy to achieve the goals of a particular organization. In educational institutions, strategic management is used to achieve the goals of the institution, namely educational institutions that have good quality education to make educational institutions have high competitiveness to maintain their existence.

\subsection{Stages in Strategic Management}

Several experts explain the stages of strategic management. According to David, the management process consists of three stages, namely strategy formulation, strategic implementation or implementation, and strategy evaluation. ${ }^{24}$

a. Strategy Formulation

The strategic management stage begins with strategy formulation. Strategy formulation is the process of selecting the main action patterns to realize the vision of the organization. The decision-making process to establish a strategy seems to be a sequence starting from establishing a mission, vision, long-term goals, SWOT analysis. ${ }^{25}$ Vision is a description of the desired state in the future, while the mission is determined by considering the formulation of assignments related to the future and the current situation. ${ }^{26}$

According to Nilasari, vision and mission are non-specific guidelines for an organization that has a purpose. ${ }^{27}$ According to Assauri, vision and mission are simple statements about the goals an organization will achieve in the future. ${ }^{28}$ So it can be concluded that the vision and mission of educational institutions is a formulation of views to achieve the aims and objectives of educational institutions. The preparation of the vision and mission must include all components of human resources in educational institutions. For this reason, the formulation must go through stages and

\footnotetext{
${ }^{24}$ Fred R. David, Manajemen strategiks: Konsep (Jakarta : Salemba Empat, 2005), 6.

${ }^{25}$ Tedjo Tripomo dan Udan, Manajemen Strategik, (Bandung : Rekayasa Sains, 2005), 28.

${ }^{26}$ E. Mulyasa, Manajemen \& Kepemimpinan Kepala Madrasah (Jakarta: Bumi Aksara, 2011), 165.

${ }^{27}$ Nilasari, Manajemen strategik itu Gampang untuk pemula \& orang awam (Jakarta : Dunia Cerdas, 2014$), 30$.

${ }^{28}$ Sofjan Assauri, Manajemen Pemasaran (Jakara: Rajawali Pers, 2013), 17.
} 
full concentration because it will give direction to where the educational institution will be taken.

SWOT analysis is the identification of various factors systematically to formulate a company strategy. This analysis is based on the logic that can maximize strengths and opportunities. But at the same time a strategy that can minimize weaknesses and threats. According to Siagian, SWOT analysis is one of the most powerful analytical instruments when used properly. This efficacy lies in the ability of strategy makers to maximize the role of strength factors and take advantage of opportunities so that they act as a tool to minimize weaknesses in the organization and reduce the impact of threats that arise and must be faced. ${ }^{29}$

b. Strategy Implementation

To achieve success, the strategy that has been successfully formulated needs to be realized with careful implementation actions. Strategy and other organizational elements must be appropriate and must be reflected in the design of the organizational structure, organizational culture, leadership, and human resource management system. One of them is the reward system. ${ }^{30}$

Strategy implementation is the theoretical process of management putting its strategies and policies into action through the development of programs, budgets, and procedures. ${ }^{31}$ In the act of managing organizational resources, management is the one who directs and controls their use through the chosen strategy. Strategy implementation is needed to detail more clearly and precisely the actual process of realizing the strategic choices that have been taken. ${ }^{32}$

c. Strategy Evaluation

To realize an optimal strategy implementation, it is necessary to evaluate the implementation so that if necessary, appropriate corrective actions can be taken. ${ }^{33}$ Strategy evaluation is a process through which company activities and work results are

\footnotetext{
${ }^{29}$ Sondang P. Siagian, Manajemen Stratejik...,172-173.

${ }^{30}$ Tedjo Tripomo dan Udan, Manajemen strategik...,28.

${ }^{31}$ David J. Hunger dan Thomas L. Wheelen, Manajemen strategiks..., 17.

${ }^{32}$ Haris, Amirullah, dan Budiyono, Pengantar Manajemen (Yogyakarta: Graha Ilmu, 2004), 119.

${ }^{33}$ Tedjo Tripomo dan Udan, Manajemen Strategik...,28
} 
monitored and actual performance is compared with desired performance. Managers at all levels use performance result information to take corrective action and solve problems. ${ }^{34}$

Strategy evaluation is a control that follows the strategy that is being implemented, detects problems or changes that occur in its rationale, and makes necessary adjustments. ${ }^{35}$ In this evaluation stage, it will be seen whether the suitability of the implementation of the strategy is following the formulation of the strategy or not or the validity of the assumptions used in the environmental analysis and vice versa. The results of this strategic control phase will be very useful and will be input for the organization's next strategic management process. ${ }^{36}$

\subsection{Organizational culture}

The use of the term organizational culture refers to the prevailing culture within the company because in general, the company is a form of organization, namely cooperation between several people who form a separate group or work unit. The following are some definitions of organizational culture put forward by experts. According to Schein organizational culture is defined as follows. "Organizational culture can be defined as the pattern of shared basic assumptions that a group learns when solving problems of external adaptation and internal integration." ${ }^{37}$

Robbins and Judge define organizational culture as, "Organizational culture refers to a system of shared meaning held by members that distinguish the organization from other organizations." 38 Organizational culture is a system of shared meaning held by members that distinguish one organization from another. This definition can be translated that organizational culture is a shared set, taken to provide an implicit assumption that the group holds and determines the way of viewing, thinking, and reacting to various environments.

Several other figures also mentioned the meaning of organizational culture, among others, Robin in his book defines organizational culture as a value system that is shared by all

\footnotetext{
${ }^{34}$ David J. Hunger dan Thomas L. Wheelen, Manajemen strategiks...,19.

${ }^{35}$ Haris, Amirullah, dan Budiyono, Pengantar Manajemen...,122.

${ }^{36}$ Setiawan Hari Purnomo dan Zulkiefli Mansyah, Manajemen strategik (Jakarta: Fakultas Ekonomi, 2007$), 14$.

${ }^{37}$ Schein, H. Edgard, Organizational Culture and Leadership (Jossey Bass, 2010), 18.

${ }^{38}$ Stephen P Robbin, Timoty Judge, Perilaku Organisasi: Organizational Behavior (Salemba: Jakarta, 2013 ), 502.
} 
members of the organization and at the same time makes it different from other organizations. ${ }^{39}$ Kreitner defines organizational culture as a form of perception that is owned, believed, and accepted by all group members as well as determines how group members feel, think about, and respond to the various environments they face.

Many researchers agree that organizational culture is an ideology that unifies an organization and is a product form of social interaction influenced by all members of the organization. Kast and Rosenzweig, in Robins, ${ }^{40}$ defines it as a system of shared values and beliefs that interact with a company's people, organizational structures, and control systems to produce behavioral norms.

\subsection{Characteristics of Madrasa}

One form of Islamic educational institution is the madrasa. Madrasas have different characteristics compared to other Islamic educational institutions such as Islamic boarding schools. Madrasas are a natural continuation of the mosque which in the early days of the Abbasid caliphate government $(132$ - $656 \mathrm{H} / 750$ - 1258 AD) became a center for the development of Islamic education. ${ }^{41}$

Madrasah literally can be translated into the word school, because practically both have in common, namely as a place for formal teaching and learning activities to take place. However, Karel Steenbrink distinguishes between madrasas and schools because they have different characteristics. Madrasas have their curriculum, methods, and ways of teaching that are different from schools. Madrasas are very prominent in the religious values of their people. While schools are public educational institutions with universal lessons and are influenced by the climate of Western enlightenment. ${ }^{42}$

Madrasah in the last decade is an alternative educational institution that is growing rapidly in the Islamic world. Despite being in the circle of modern educational institutions and facing severe challenges, madrasas still maintain their distinctive characteristics. In the

\footnotetext{
${ }^{39}$ Stephen C Robbins, Organizational Behavior, Concept Controversies and Applications, Prentice Hall Inc. USA. Terjemahan ( Jakarta: P.T. Indeks Kelompok Gramedia, 2003), 102.

${ }^{40}$ Ibid, 125

${ }^{41}$ Badri Yatim, Sejarah Peradaban Islam, (Jakarta: PT. RajaGrafi ndo Persada, 2004), 50. lihat juga Ediwarman, Madrasah Nizamiyah, Pengaruhnya terhadap Perkembangan Pendidikan Islam, dalam Samsul Nizar (ed.), Sejarah Pendidikan Islam, Menelusuri jejak sejarah Era Rasulullah sampai Indonesia, (Jakarta: Kencana Prenada Media Group, 2007), 157.

${ }^{42}$ Karel A. Steenbrink, Pesantren, Madrasah, sekolah (Jakarta : LP3ES, 1991), 46
} 
history of the birth of Islamic education, the madrasa is a very old formal education. However, when faced with the actual problems of Muslims, it turns out that the existence of madrasas has not yet found a definite identity. Even though during the crisis of modern civilization today, mankind has a lot of hope in Islam and this hope must be immediately answered by madrasa managers, because it is in this madrasa that Islam is taught with all its wealth and dimensions that never dry up and never a crisis. ${ }^{43}$

\section{RESEARCH METHODS}

This study uses a qualitative approach. Qualitative research is a particular tradition in the social sciences that is fundamentally dependent on observing humans in their comrades and dealing with these people in their language and their language. ${ }^{44}$ This approach is often referred to as field research. ${ }^{45}$ Sugiyono mentions qualitative research as a naturalistic research method because the research is carried out in natural conditions (natural settings). ${ }^{46} \mathrm{~A}$ qualitative approach according to Best, as quoted by Sukardi is a research method that seeks to describe and interpret objects by what they $\operatorname{are}^{47}$. Likewise, Prasetya revealed that qualitative research is research that explains facts as they $\operatorname{are}^{48}$.

Judging from the type of qualitative approach, this research is included in the naturalistic phenomenological category. This is because research from a phenomenological perspective means understanding events with people in certain situations. This is according to Bogdan's opinion that to understand the meaning of events and people's interactions, theoretical orientation or a theoretical perspective with a phenomenological approach is used. ${ }^{49}$

\section{RESEARCH FINDINGS AND DISCUSSION}

\subsection{Strategic Planning for Strengthening Madrasah Organizational Culture.}

\footnotetext{
${ }^{43}$ Fathor Rachman Utsman dan Muhammad Husnan, Jurnal Hikmah, Vol. XI, No. 2, 2015

${ }^{44}$ Lexi J. Moleong, Metodologi Penelitian Kualitatif, (Bandung: PT. Remaja Risda Karya, 2002), 135.

${ }^{45}$ Muhammad Nazir, Metode Penelitian, (Bandung: Remaja Rosdakarya, 1986), 159.

${ }^{46}$ Sugiyono, Metode Penelitian Kuantitatif Kualitatif dan R\&D, (Bandung: Alfabeta, 2014), 8.

${ }^{47}$ Sukardi, Metode Penelitian Pendidikan: Kompetensi dan Prakteknya, (Jakarta: Bumi Aksara, 2005), 157

${ }^{48}$ Prasetya Irawan, Logika dan Prosedur Penelitian : Pengantar Teori dan Panduan Praktis Penelitian Sosial bagi Mahasiswa dan Peneliti Pemula, (Jakarta: STAIN, 1999), 59

${ }^{49}$ Robert C. Bogdan dan Sari Knopp Biklen, Qualitative Research for Education: An Introduction to Theory and Methods, (Boston: Aliyn and Bacon, Inc., 1998), 31
} 
The strategic management planning carried out at MTsN 16 Jombang and MTsN 1 Ponorogo in the description above is following the concept of strategic management planning written by R David, namely, the stage of formulating strategies, among others, setting a vision and mission, identifying opportunities and challenges faced by the organization from the point of view of external point of view, determine the weaknesses and strengths of the organization from an internal point of view, develop long-term plans, make alternative strategies and choose certain strategies to be achieved. ${ }^{50}$

The concept of strategic management planning applied at MTsN 16 Jombang and MTsN 1 Ponorogo is also following the concept of strategic management planning according to Wheelen-Hunger and Akdon. Wheelen-Hunger explained that the strategic management planning stage consists of environmental observation and strategy formulation. Environmental observation is in the form of external and internal analysis while strategy formulation consists of developing long-term plans for effective management of environmental opportunities and threats, judging from the strengths and weaknesses of the madrasa, which are outlined in the formulation of the vision, mission, goals, strategies, and policies ${ }^{51}$ Akdon describes strategic planning activities as strategy preparation closely related to the main functions of the organization which are clearly stated in the organization's mission statement. The strategy formulated is also practical because it is action-oriented based on the results of testing internal and external factors. Specifically, Akdon identifies things that must be considered in formulating strategies, namely (1) determining the vision, mission, goals, and objectives to be achieved appropriately so that they can be used as an operational reference for organizational activities, especially in achieving the organization's final goals; (2) recognize the environment in which the organization is located; (3) conduct a useful analysis in the organization's positioning to maintain its existence and carry out its objectives. ${ }^{52}$

The peculiarity of the findings in this study is that strategic management planning at MTsN 16 Jombang and MTsN 1 Ponorogo was carried out by involving all components of

\footnotetext{
${ }^{50}$ Fred R David, Strategic Management: Concepts, (Upper Saddle River, N.J. : Prentice Hall, 2011), 119

${ }^{51}$ Hunger, J David and Thomas L Wheelen. Management Strategis. Terj.Juianto Agung.Ed.2.( Yogyakarta : Andi, 2003), 8.

${ }^{52}$ Akdon, Strategic Manajemen for Educational Management:Manajemen Strategiks untuk Manajemen Pendididkan, (Bandung, ALFABETA, 2006),82.
} 
madrasas and experts as well as a formulation with a spirit of togetherness, kinship and based on religious values. All components of the madrasa which consist of the principal, educators, and education staff, parents/guardians, and madrasah committees are involved in planning activities to obtain a strategy formulation that truly fits the needs and encourage all components of the madrasa to be responsible for its implementation. Experts can come from supervisors and educational practitioners involved to obtain innovative and creative planning formulations so that they will be more effective in achieving the goals that have been set.

\subsection{Implementation of Strategy for Strengthening Madrasah Organizational Culture}

In the implementation of strategic management, strengthening the organizational culture of madrasas at MTsN 16 and MTsN 1 Ponorogo is manifested in the form of activities. These activities are in the form of program formulation as a derivative or elaboration of the strategic program formulation determined in the planning stage, preparation of organizational structure and placement of human resources by their competencies, preparation of program implementation procedures guidelines, budgeting by applicable regulations, and continuous monitoring of activities. As for the implementation of the strategy, it is carried out team-based (teamwork) based on Islamic values.

Furthermore, the programs implemented by the two institutions can be concluded to have shown serious efforts to realize the characteristics of a strong organizational culture. These programs consist of a. strategic program for the development of work culture values $b$. HR development strategic program; c. strategic programs to build a culture of academic and non-academic excellence; $d$. strategic program of quality assurance of the learning process; e. strategic programs to build a disciplined culture of madrasas; f. strategic programs to build a conducive work environment.

The implementation of strategic management at MTsN 16 Jombang and MTsN 1 Ponorogo also aligns with the concept of strategy implementation by Wheelen-Hunger, Robinson, and Akdon. Wheelen-Hunger states that strategy implementation is the management process of putting its strategies and policies into action through the development 
of programs, budgets, and procedures. ${ }^{53}$ Robinson explained that implementing strategic choices by allocating budgetary resources emphasizes the compatibility between tasks, human resources, structure, technology, and reward systems through restructuring (rearranging), reengineering (updating tools), and refocusing organization (rearranging organizational goals). ${ }^{54}$ Meanwhile, according to Wheelen-Hunger, strategy implementation must be carried out at least through three actions, namely program development, budgeting, and determining as well as implementing procedures. According to Robinson, allocating budgetary resources emphasizes the compatibility between tasks, human resources, structure, technology, and reward systems through restructuring (rearranging), reengineering (updating tools), and refocusing the organization (rearranging organizational goals).

Akdon also stated the same thing that strategy implementation is the act of implementing strategies that have been arranged into various optimal allocations of resources. In other words, in implementing the strategy we use strategic formulations to help establish performance objectives, allocate and prioritize resources. ${ }^{55}$

The implementation of strategic management to strengthen organizational culture at MTsN 16 Jombang and MTsN 1 Ponorogo can also be concluded to have shown a strong effort to create a good madrasa organizational culture. It can be explained that the development programs as the implementation of strategic management have met the criteria as efforts to realize the characteristics of a strong organizational culture. This is following Luthan's opinion. ${ }^{56}$ The peculiarity of MTsN 16 Jombang and MTsN 1 Ponorogo in implementing strategic management for strengthening the organizational culture of madrasas is the clear division of tasks/job descriptions. In addition, there are measurable indicators of program achievement, implemented on a team basis and accompanied by proportional and sustainable monitoring. With a clear division of tasks or job descriptions that will streamline program implementation and minimize miscommunication, the existence of program achievement indicators will provide a more focused implementation direction, team-based

${ }^{53}$ Hunger, J David and Thomas L Wheelen. Management Strategis.Terj.Juianto Agung.Ed.2.(Yogyakarta : Andi, 2003), 69

54 John A. Pearce II dan Richard B.Robinson, Jr., Manajemen strategiks Formulasi, Implementasi dan Pengendalian. (Jakarta : Salemba Empat, 2008), 24

${ }^{55}$ Akdon, Strategic Manajemen..., 82-83.

${ }^{56}$ Luthan, F. 1995. Organizational Behavior. Singapore: McGraw-Hill, Inc., 122 
implementation will be able to create a warm and conducive work climate and monitoring will better guarantee the implementation of the program.

\subsection{Evaluation of Strategy for Strengthening Madrasah Organizational Culture}

MTsN 16 Jombang and MTsN 1 Ponorogo carry out strategic management evaluations by comparing performance achievements with program success indicators that have been set at the beginning. Evaluation activities are carried out by involving all components of the madrasa and external parties by prioritizing the principles of togetherness, kinship, and openness as well as religious values to obtain objective evaluation results. Furthermore, the results of the evaluation are used as guidelines in conducting program reviews and developing better programs.

The peculiarity of the strategic management evaluation of MTsN 16 Jombang and MTsN 1 Ponorogo is the seriousness and clarity of indicators in evaluating each madrasa program, the evaluation is carried out by involving all components of the madrasa and even involving external parties for several program activities and carried out with the principle of togetherness, kinship will be based on values. - Islamic values.

The findings of the research on the evaluation of strategic management carried out at MTsN 16 Jombang and MTsN 1 Ponorogo above can be explained that the evaluation was carried out by comparing indicators of achievement with the level of program achievement. In the evaluation, an analysis of the causes or background of the occurrence of a difference in the level of program achievement is also carried out.

Furthermore, the evaluation results are used as the basis for reviewing the programs that have been implemented. With the results of the evaluation, the madrasah can determine whether the program can be continued or terminated. The results of the madrasa evaluation can increase the indicators of program achievement or decrease it. With this flow, madrasa programs will be more objective and follow the conditions in the madrasa.

The implementation of the strategic management evaluation carried out at MTsN 16 Jombang and MTsN 1 Ponorogo above is in the following theory put forward by R David and Wheelen-Hunger. Wheelen-Hunger explains that strategy evaluation is a process of 
comparing actual performance compared to desired performance. ${ }^{57}$ Likewise, Akdon stated that the main focus in strategy evaluation is the measurement and creation of an effective feedback mechanism. Performance measurement is an important stage to see and evaluate the achievements or results of work that has been carried out by the organization to achieve the goals that are the targets of the work. ${ }^{58}$

The uniqueness of the evaluation of strategic management in MTsN 16 Jombang and MTsN 1 Ponorogo is the implementation of team-based strategy evaluation (teamwork), togetherness, and kinship and based on Islamic values. With the implementation of such an evaluation, it is very possible to obtain accurate evaluation results as well as to obtain input on various obstacles encountered during implementation. The involvement of external elements in the evaluation of several madrasah programs is also a feature of strategy evaluation in the two institutions.

\section{CONCLUSION}

Based on the data exposure and cross-site findings as well as cross-site analysis of findings, the results of this study can be concluded as follows.

1. Formulation of strategies for strengthening the organizational culture of madrasas, namely carrying out internal analysis through madrasa self-evaluation (EDM) and carrying out SWOT analysis. The results of the two analyzes are used as the basis and reference in the formulation of the strategy formulation as outlined in the four-year medium-term program in the form of a madrasa work plan. Thealysis and preparation of strategic planning activities are carried out by a team appointed by the head of the madrasa who is a representative of all components of the madrasa.

2. Implementation of strategies for strengthening the organizational culture of madrasas, namely carrying out program formulation activities as a derivative or elaboration of the strategic program formulation determined in the planning stage, preparation of organizational structure and placement of human resources in following their competencies,

\footnotetext{
${ }^{57}$ Hunger, J David and Thomas L Wheelen.. Management Strategis.Terj.Juianto Agung.Ed.2.( Yogyakarta: Andi, 2003), 8

${ }^{58}$ Akdon, Strategic Manajemen..., 84.
} 
preparation of program implementation procedures guidelines, budgeting by applicable regulations and monitoring activities continuously.

3. Implementation of strategies for strengthening madrasah organizational culture by carrying out clear division of tasks/job descriptions, formulating measurable program achievement indicators, implementing team-based (teamwork), and accompaniment with proportional and sustainable monitoring.

4. The evaluation of the strategy for strengthening the madrasa organizational culture is carried out by comparing performance achievements with indicators of program success that have been set at the beginning. Evaluation activities are carried out by involving all components of the madrasa and external parties by prioritizing the principles of togetherness, kinship, and openness as well as religious values to obtain objective evaluation results.

\section{REFERENCE}

Akdon, Strategic Management for Educational Management, (Bandung: Alfabeta, 2006)

Angel Caroline Lukito, Devine, Pengaruh Budaya Perusahaan terhadap Keunggulan Bersaing Melalui Kepuasan Karyawan pada Perusahaan Kafe Restoran di Surabaya (Surabaya: Jurnal Business Accounting Review, Vol. 3, No. 1, Januari 2015)

Aries Musnandar, Implementasi Manajemen strategik dalam Pengembangan Budaya Organisasi pada Perguruan Tinggi Islam: Studi Kasus di UIN Maliki Malang” ( Jurnal Ulul Albab Volume 14, no.1 Tahun 2013 )

Badri Yatim, Sejarah Peradaban Islam, (Jakarta: PT. RajaGrafi ndo Persada, 2004), 50. lihat juga Ediwarman, Madrasah Nizamiyah, Pengaruhnya terhadap Perkembangan Pendidikan Islam, dalam Samsul Nizar (ed.), Sejarah Pendidikan Islam, Menelusuri jejak sejarah Era Rasulullah sampai Indonesia, (Jakarta: Kencana Prenada Media Group, 2007)

Bandana Nayak, Anil Barik, Assessment Of The Link Between Organizational Culture and Job Satisfaction (Study of An Indian Public Sector) (International Journal Of Informations Business and Management, 2013, Vol. 5, No. 4).

David J. Hunger dan Thomas L. Wheelen, Manajemen strategis, terj. Julianto Agung S (Cet. 16, Yogyakarta: Andi, 2003)

E. Mulyasa, Manajemen \& Kepemimpinan Kepala Madrasah (Jakarta: Bumi Aksara, 2011), 165. 
Eny Wahyu Suryanti, Pengembangan Budaya Organisasi di Sekolah (Jurnal Likhitaprajna Volume 19, Nomor 1)

Fathor Rachman Utsman dan Muhammad Husnan, Jurnal Hikmah, Vol. XI, No. 2, 2015

Fred R David, Strategic Management: Concepts, (Upper Saddle River, N.J. : Prentice Hall, 2011), 119

Freddy Rangkuti, Analisis SWOT Teknik Membedah Kasus Bisnis (Jakarta : PT Gramedia Pustaka Utama)

George R. Terry, Prinsip-Prinsip Manajemen, terj. J. Smith D.F.M (cet. 10, Jakarta : PT Bumi Aksara)

Golnaz Sadri dan Brian Lees, Developing Corporate Culture As a Competitive Advantage(The Journal Of Management Development, Vol. 20, No. 10, 2001)

Gunawan, Manajemen Strategik dalam Mewujudkan Kemandirian Pondok Pesantren (Studi Multisitus di Pondok Pesantren Sidogiri Pasuruan dan Pondok Pesantren Al-Ishlah Bondowoso), Disertasi (Malang: Pascasarjana UIN Malang, 2014).

Hadari Nawawi, Manajemen Strategik Organisasi Non Profit Bidang Pemerintahan dengan Ilustrasi di Bidang Pendidikan (Cet. III, Yogyakarta: Gadjah Mada University, 2005) Haris, Amirullah, dan Budiyono, Pengantar Manajemen (Yogyakarta: Graha Ilmu, 2004), 119.

Hunger, J David and Thomas L Wheelen.. Management Strategis.Terj.Juianto Agung.Ed.2.( Yogyakarta: Andi, 2003)

J. Salusu, Pengambilan Keputusan Strategi untuk Organisasi Publik dan Organisasi Nonp rofit (Jakarta: Grasindo, 2008)

John A. Pearce II dan Richard B.Robinson, Jr., Manajemen strategiks Formulasi, Implementasi dan Pengendalian. (Jakarta : Salemba Empat, 2008)

John Echols dan Hasan Syadily, Kamus Inggris Indonesia (Jakarta: Gramedia, 1996)

Karel A. Steenbrink, Pesantren, Madrasah, sekolah (Jakarta : LP3ES, 1991)

Kreitner R \& Kinicki A, Organizational Behavior (New York:Mc Graw Hill Companies, Inc., 2001 )

Lawrence R. Jauch dan Wiliam F. Gluech, Manajemen strategiks dan Kebijakan Perusahaan (Jakarta : Erlangga, 1998)

Lexi J. Moleong, Metodologi Penelitian Kualitatif, (Bandung: PT. Remaja Risda Karya, 2002) 
Luthan, F. 1995. Organizational Behavior. Singapore: McGraw-Hill, Inc.,

Muhammad Nazir, Metode Penelitian, (Bandung: Remaja Rosdakarya, 1986)

Nilasari, Manajemen strategik itu Gampang untuk pemula \& orang awam (Jakarta : Dunia Cerdas, 2014)

Pius A. Partanto \& M. Dahlan Al Barry, Kamus Ilmiah Populer (Surabaya : Arkola, 2001)

Prasetya Irawan, Logika dan Prosedur Penelitian : Pengantar Teori dan Panduan Praktis Penelitian Sosial bagi Mahasiswa dan Peneliti Pemula, (Jakarta: STAIN, 1999)

Robert C. Bogdan dan Sari Knopp Biklen, Qualitative Research for Education: An Introduction to Theory and Methods, (Boston: Aliyn and Bacon, Inc., 1998)

S. Ali Jadid Al Idrus, Manajemen Strategik Pengembangan Pendidikan Tinggi di Pondok Pesantren (Studi Multisitus di Pondok Pesantren Salafiyah Syafi'ah Sukorejo Situbondo, Pondok Pesantren Qomarul Huda Bagu Lombok Tengah, dan Pondok Pesantren Darunnahdlatain Nahdlatun Wathan Pancor Lombok Timur), Disertasi (Malang: Pascasarjana UIN Malang, 2014).

Schein, H. Edgard, Organizational Culture and Leadership (Joosey Bass, 2010)

Setiawan Hari Purnomo dan Zulkiefli Mansyah, Manajemen strategik (Jakarta: Fakultas Ekonomi, 2007)

Sofjan Assauri, Manajemen Pemasaran (Jakara: Rajawali Pers, 2013)

Sondang P. Siagian, Manajemen Stratejik (Jakarta : Bumi Aksara, 2005)

Stephen C Robbins, Organizational Behavior, Concept Contropversies and Applications, Prentice Hall Inc. USA. Terjemahan ( Jakarta: P.T. Indeks Kelompok Gramedia, 2003)

Sugiyono, Metode Penelitian Kuantitatif Kualitatif dan R\&D, (Bandung: Alfabeta, 2014)

Sukardi, Metode Penelitian Pendidikan: Kompetensi dan Prakteknya, (Jakarta: Bumi Aksara, 2005)

Sylvia J. Flatt, Stanley J. Kowalczyk, Creating Competitive Advantage Through Intagible Asset: The Direct and Indirect Effects of Corporate Culture and Reputations (Advances in Competitiveness Research, Vol. 16, 1\&2, 2008)

Tedjo Tripomo dan Udan, Manajemen Strategik, (Bandung : Rekayasa Sains, 2005) 